\title{
Selection of bee species for environmental risk assessment of GM cotton in the Brazilian Cerrado
}

\author{
Carmen Sílvia Soares Pires(1), Fernando Amaral Silveira(2), Carolina Ferreira Cardoso ${ }^{(2)}$, Edison Ryotii Sujii( ${ }^{(1)}$, \\ Débora Pires Paula(1), Eliana Maria Gouveira Fontes ${ }^{(1)}$, Joseane Padilha da Silva ${ }^{(1)}$, \\ Sandra Maria Morais Rodrigues ${ }^{(3)}$ and David Alan Andow ${ }^{(4)}$
}

\begin{abstract}
(1)Embrapa Recursos Genéticos e Biotecnologia, Caixa Postal 02372, CEP 70770-917 Brasília, DF, Brazil. E-mail: carmen.pires@embrapa.br, edison.sujii@embrapa.br, debora.pires@embrapa.br, eliana.fontes@mma.gov.br, joseane.padilha@embrapa.br (2)Universidade Federal de Minas Gerais, Departamento de Zoologia, Instituto de Ciências Biológicas, Caixa Postal 486, CEP 30161-970 Belo Horizonte, MG, Brazil. E-mail: f.a.silveira.ufmg@gmail.com, carolyfc@yahoo.com.br ${ }^{(3)}$ Embrapa Algodão, Caixa Postal 343, CEP 78550-970 Sinop, MT, Brazil. E-mail: sandra.rodrigues@embrapa.br ${ }^{(4)}$ University of Minnesota, 219 Hodson Hall, 1980, Folwell Avenue, St. Paul, 55108, MN, USA. E-mail: dandow@umn.edu
\end{abstract}

Abstract - The objective of this work was to list potential candidate bee species for environmental risk assessment (ERA) of genetically modified (GM) cotton and to identify the most suited bee species for this task, according to their abundance and geographical distribution. Field inventories of bee on cotton flowers were performed in the states of Bahia and Mato Grosso, and in Distrito Federal, Brazil. During a 344 hour sampling, 3,470 bees from 74 species were recovered, at eight sites. Apis mellifera dominated the bee assemblages at all sites. Sampling at two sites that received no insecticide application was sufficient to identify the three most common and geographically widespread wild species: Paratrigona lineata, Melissoptila cnecomola, and Trigona spinipes, which could be useful indicators of pollination services in the ERA. Indirect ordination of common wild species revealed that insecticides reduced the number of native bee species and that interannual variation in bee assemblages may be low. Accumulation curves of rare bee species did not saturate, as expected in tropical and megadiverse regions. Species-based approaches are limited to analyze negative impacts of GM cotton on pollinator biological diversity. The accumulation rate of rare bee species, however, may be useful for evaluating possible negative effects of GM cotton on bee diversity.

Index terms: Gossypium hirsutum, biological diversity, ecological risk assessment, pollination services, transgenic crops, wild bees.

\section{Seleção de espécies de abelhas para avaliação de risco ambiental de algodoeiro GM no Cerrado brasileiro}

Resumo - O objetivo deste trabalho foi listar espécies de abelhas candidatas potenciais para análise de risco ambiental (ARA) de algodoeiros geneticamente modificados (GM) e identificar as espécies de abelhas mais adequadas para essa finalidade, de acordo com sua abundância e distribuição geográfica. Inventários de abelhas em flores de algodoeiro foram realizados nos estados da Bahia e do Mato Grosso, e no Distrito Federal. Durante 344 horas de amostragem, foram coletadas 3.470 abelhas de 74 espécies, em oito locais. Apis mellifera dominou as assembleias de abelhas em todos os locais. A amostragem em dois locais que não receberam aplicação de inseticidas foi suficiente para identificar as três species de abelhas silvestres mais comuns e de distribuição geográfica mais ampla: Paratrigona lineata, Melissoptila cnecomola e Trigona spinipes, as quais poderiam ser usadas como indicadoras de serviços de polinização na ARA. A ordenação indireta de espécies silvestres comuns revelou que os inseticidas reduziram o número de espécies de abelhas nativas e que a variação interanual nas assembleias de abelhas pode ser baixa. As curvas de acumulação de espécies raras de abelhas não saturaram, conforme esperado em regiões tropicais e megadiversas. As abordagens baseadas em espécies são limitadas para avaliar os impactos negativos de algodoeiros GM sobre a diversidade biológica de polinizadores. A taxa de acumulação de espécies raras de abelhas, no entanto, pode ser útil para avaliar os possíveis efeitos negativos de algodoeiros GM sobre a diversidade de abelhas.

Termos para indexação: Gossypium hirsutum, diversidade biológica, avaliação de risco ambiental, serviços de polinização, culturas transgênicas, abelhas silvestres.

\section{Introduction}

In most countries, the adoption of genetically modified (GM) crops is subject to specific legislation and, for the signatories of the Cartagena Protocol, environmental risk analysis (ERA) is required for releasing commercial GM plantations (Cartagena 
protocol on biosafety to the convention on biological diversity, 2000). To meet the demands of the Cartagena Protocol, ERA should be conducted on a case by case basis, taking into account the characteristics expressed by the transgene and the environment where the plants will be released.

However, ERA methodologies for GM crops have largely escaped critical review by ecologists. ERA typically has followed a model developed to assess the environmental effects of toxic chemicals (National Research Council, 1983; Andow \& Hilbeck, 2004; Suter II, 2007), such as pesticides and mining waste, that focuses on direct toxic effects but does not adequately address indirect, cascading, or any of the higher order effects of considerable importance to ecosystem functioning (Forbes \& Forbes, 1994; National Research Council, 2002; Stark et al., 2004; Andow \& Zwahlen, 2006). Furthermore, this model evaluates surrogate species and extrapolates the results to all other species in the environment (Suter II, 2007). Therefore, the same group of species has been used in environmental risk assessment regardless of the differences in proposed changes, in ecosystems at risk, and in the scale of the application. For pollinators, for example, ERA of GM crops has used the common honey bee (Apis mellifera L.) as the primary surrogate species, independently of the differences in the characteristics expressed by the transgene and in the other factors (National Research Council, 1983; Andow \& Hilbeck, 2004).

Honey bee has a significant economic value due to its pollination services, its products (honey, propolis, and wax), and the income provided for beekeepers (Van Engelsdorp \& Meixner, 2009). However, it is unlikely that the honey bee can represent all the wild bees, many of which are solitary or have different colony structures and foraging behaviors. For this reason, ERA must consider potential adverse effects on wild bees, either in addition to or in place of the honey bee.

Wild-bee diversity in the Neotropics includes approximately 5,000 described species, of which about 1,600 are known to occur in Brazil (Moure et al., 2007). Hundreds of these species are expected to be found in Brazilian agroecosystems (Pinheiro-Machado et al., 2002), since many of the cultivated plants are good sources of pollen, nectar or both; and even more species are expected in natural habitats (Heard, 1999). Therefore, a key challenge for ERA, particularly in tropical and megadiverse countries, is selecting suitable indicator species from the wide diversity of wild flower-visiting bees.

The introduction of GM cotton cultivars in Brazil has risen important ERA issues. Flower-visiting bees were considered as an important ecological group for ERA because of the possible effects of GM cotton on pollination services in natural and in agricultural ecosystems. There are concerns about direct effects on bees, which may be caused by the ingestion of proteins encoded by transgenes, if they are expressed in pollen and nectar (Han et al., 2010). Moreover, indirect effects may occur if plant transformation inadvertently changes flower phenotype, including volatile compounds (Hare, 2011), which could affect its attractiveness to pollinators (Arpaia et al., 2011).

Since the Cartagena Protocol, new approaches have been discussed and proposed by different scientific forum for ERA of GM plants (Hayes, 2002; Andow \& Hilbeck, 2004; Hill, 2005; Sensi, 2011; Sanvido et al., 2012; Andow et al., 2013). However, which nontarget species should be evaluated in risk assessments of GM plants is still under debate. For megadiverse countries, such as Brazil, one of the challenges in environmental risk assessment is the difficulty in choosing species to be considered in the analysis, due to: the high diversity of species associated with natural and agricultural ecosystems; the lack of reliable information on biodiversity; and the lack of scientific criteria for choosing species that may actually indicate risk. Rectifying these limitations is a challenge to ecologists.

One ecological approach to species selection for ERA has been proposed (Hilbeck et al., 2006) and tailored for pollinators (Arpaia et al., 2006; Hong al., 2008). This approach was specifically aimed at transgenic plants, but should be adaptable to many other agriculture technologies. The ecological approach to species selection considers the local biodiversity associated with the environment where the transgenic plant will be released and uses multi-criteria decision analysis (MCDA) to prioritize the species known to exist in the release environment (Andow et al., 2013). The MCDA uses two sets of ecological criteria: one to rank the potential exposure of each species to the novel environmental stressor (in this case a transgenic plant), and the other to rank the potential magnitude of the adverse environmental consequences should the 
species be exposed and affected by the novel stressor (Andow et al., 2013). The first set of ecological criteria ranks the species based on their geographical distribution and abundance; the second group of criteria takes into account the species functional role in the agroecosystems. With this approach, the species that are potentially more exposed to the GM crop and have greater functional significance are prioritized to be used in the next step of the risk assessment evaluation.

The influence of the variation of bee assemblages throughout the main cotton-producing region of Brazil was evaluated, regarding the process of species selection (MCDA), as proposed by Arpaia et al. (2006). The lack of knowledge about local biodiversity and uncertainties in data collection were considered to evaluate the data demands for the first steps in conducting an ERA for the potential effects of transgenic cotton on bee species in the country.

The objective of this work was to select potential candidate bee species for ERA of GM cotton and to identify the most suited bee species for this task, according to their abundance and geographical distribution.

\section{Materials and Methods}

The field study was carried out in Central-West region of Brazil, which is the main cotton-producing region of the country (Companhia Nacional de Abastecimento, 2012), in three localities: two states - Bahia and Mato Grosso -, and the federal district - Distrito Federal (Figure 1). The region is located in the Cerrado phytogeographic domain, which has been intensively and extensively exploited by agriculture since the 1990's (Sparoverk et al., 2010). Cotton (Gossypium hirsutum L. var. latifolium Hutch) fields were sampled during the cotton flowering periods, from 2003 to 2006 (Table 1). Bees were collected at eight "site-years", defined as a location sampled in a particular year. The areas sampled ranged from 0.15 to 12 ha. Overall, the landscapes surrounding the sampling areas consisted of a mix of pastures, other crops, native riparian forests and Cerrado vegetation, although most of the native vegetation was highly disturbed.

The sampling areas were located near remaining natural vegetation, considering that the goal was to characterize the assemblage of wild bees visiting the cotton flowers and that these insects are highly dependent on natural environments for nesting and feeding resources (Kremen et al., 2007). In general, crop fields in the Cerrado biome extend over large areas (usually larger than $500 \mathrm{ha}$ ) with natural vegetation restricted to the field margins. Because chemicals used for pest control can interfere in the inventory results (Dormann et al., 2007; Le Féon et al., 2010; Brittain \& Potts, 2011), it was necessary to check the influence of insecticide use on bee assemblage associated with the cotton crop. Therefore, a total of eight fields were sampled: four fields subjected to insecticide applications (10-18 applications during the crop season), and four fields in which caterpillar control was made only three times with the biological insecticide Dipel (Bacillus thuringiensis).

A standard methodology for sampling flower visitors was developed based on the discussion and suggestions by Silveira \& Godinez (1996), and used in all site-years. Briefly, it is a visual sampling method in which the entire sampling area is slowly traversed and inspected, and all insects found inside the flowers, or hovering just above them, or at the extra-floral nectaries are collected. The insects were captured using

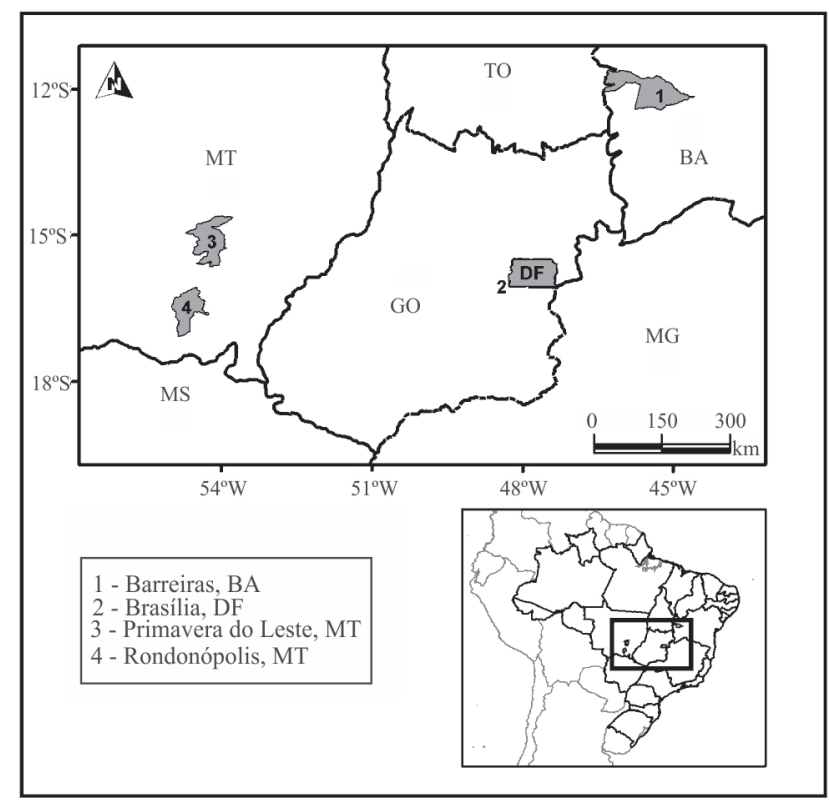

Figure 1. Geographical location of sampling sites in the main cotton-producing region of Brazil, in the municipalities of Barreiras, in the state of Bahia (BA); Primavera do Leste and Rondonópolis, in the state Mato Grosso (MT); and in Brasília, in Distrito Federal (DF). 
plastic bottles placed directly on the flowers, so that the bees came naturally into the bottles when leaving the flowers. The sampling procedure was executed weekly during the flowering season, typically from February to April. Each sample comprised at least 1 hour between 7:00 a.m. and 12:00 p.m., preferably on sunny days with temperatures above $15^{\circ} \mathrm{C}$, which is when bees are most active.

During 2003 and 2005, all insects associated with the flowers were collected, because the collectors did not have the capacity to discriminate bees from others insects. During 2004 and 2006, the collectors could discriminate bees from other flower visitors, and only bees were sampled. Sampling effort averaged 43 hours per site-year and ranged from 16.3 to 67.5 hours. The relative abundance of each species, at each site-year, was estimated by dividing the number of individuals in the sample by the number of sampling hours. The use of these frequencies allows for the comparison of bee abundance in the samples obtained in different sites, by a different number of collectors with different sampling effort (Silveira \& Godinez, 1996). The bees were identified in the bee systematics and ecology lab from the Department of Zoology of Universidade Federal de Minas Gerais (UFMG), in the state of Minas Gerais, Brazil. Bee specimens were deposited in the Entomological Collection of the Taxonomic Collections of the UFMG.
Species accumulation curves for bees were plotted combining data from all site-years in a locality (Bahia, Mato Grosso or Distrito Federal), in order to determine if the sampling effort was sufficient to capture a sound diversity of bee species in each of the three localities. Because of the interest both in the common species, for evaluating pollinator services, and in the rare species, for assessing pollinator species diversity, species accumulation curves were examined for the common species ( $>5$ specimens per species) and for all of the species (both rare and common species). The bee assemblages at each site-year were characterized with species rank-abundance curves. The species diversity in each sampling region was described by species richness, and by the Shannon-Weiner $\left(\mathrm{H}^{\prime}\right)$ and Simpson (D) indexes. The Kruskal-Wallis test was used to compare the number of species and their relative abundance between sites that received insecticide applications and those that did not.

The most common bee species was determined by dropping all taxa with fewer than five specimens in the entire sample. In many agricultural habitats, the common bee species will provide nearly all of the pollination services (Kremen et al., 2007). Only pollination services provided by obligate specialistbees will likely be missed by this analysis. Two approaches were used to address how well the bee assemblage at a single site-year represents the entire sample of

Table 1. Characteristics of the study areas in which bee sampling was conducted on cotton (Gossypium hirsutum var. latifolium) in three localities in Central-West region of Brazil: the states of Bahia and Mato Grosso and the federal district, Distrito Federal, from 2003 to 2006.

Characteristics of the studied areas

Bahia

Barreiras town, three commercial farms (3 ha sampling area), sampled between May $7^{\text {th }}$ and May $29^{\text {th }}$ in 2005 , sampling effort of 60 hours, with insecticide use and irrigation, near native vegetation and commercial fields, Delta Opal and Acala cotton varieties.

Mato Grosso

a. Primavera do Leste, commercial farm and experimental cotton field of Embrapa (12 ha sampling area), sampled between February $25^{\text {th }}$ and July $7^{\text {th }}$ in 2005, sampling effort of 67.5 hours, with insecticide use and irrigation, near a disturbed Cerrado fragment, 17 different cotton cultivars planted.

b. Rondonópolis, experimental field of an university ( 0.8 ha sampling area), sampled between February $15^{\text {th }}$ and June $3^{\text {rd }}$ in 2005 , sampling effort of 43.8 hours, without insecticide use and irrigation, near a grassland and soybean field, Delta Opal cotton variety.

\section{Distrito Federal}

a. Cooperbrás farm, a commercial plantation ( 3 ha sampling area), sampled between February $5^{\text {th }}$ and June $9^{\text {th }}$ in 2003 , sampling effort of 40.5 hours, without insecticide use or irrigation, surroundings include a disturbed Cerrado tract and a riparian forest, Delta Opal cotton variety.

b. Cooperbrás farm, a commercial plantation ( 4 ha sampling area), sampled between February $27^{\text {th }}$ and May $7^{\text {th }}$ in 2004 , sampling effort of 43.2 hours, with insecticide use and without irrigation, near disturbed Cerrado vegetation, Delta Opal cotton variety.

c. Cooperbrás farm, a commercial plantation (4 ha sampling area), sampled between February $17^{\text {th }}$ and March $24^{\text {th }}$ in 2005 , sampling effort of 16.3 hours, with insecticide use and without irrigation, adjacent to disturbed Cerrado vegetation and a dirt road, Delta Opal cotton variety.

d. Experimental field at Embrapa Hortaliças (CNPH) $\left(0.15\right.$ ha sampling area), sampled between March $8^{\text {th }}$ and May $17^{\text {th }}$ in 2005 , sampling effort of 40 hours, without insecticide use and irrigation, near a corn field and a riparian area, Delta Opal cotton variety.

e. Experimental field at CNPH (0.15 ha sampling area), sampled between March $2^{\text {nd }}$ and April $24^{\text {th }}$ in 2006 , sampling effort of 33 hours, without insecticide use or irrigation, near a corn field and a riparian area, Delta Opal cotton variety. 
eight site-years. The first approach was indirect ordination, which enables to identify environmental factors that cause the bee assemblages to differ. The second approach was sample randomization, in order to determine how many site-years were needed to identify the most common bee species. Principal component analysis (PCA) was used to ordinate the sites, after applying a $\log +1$ transformation to the original data. Similarity between assemblages at each site was measured using the Renkonen index, which is not heavily affected by sample size and species diversity (Krebs, 1998). The bioconductor package in the R software, version 2.11.1, was used for statistical analysis (R Development Core Team, 2010).

Using the three most abundant wild bee species in the entire sample of eight sites and a technique similar to rarefaction, site-years were sampled randomly with replacement; one, two, or three site-years at a time. In each site-year, species were ranked by abundance, and subsets of the three, four, five, and six most abundant wild species at a site-year were obtained. For each of these subsets, the number of the three most abundant native species was recorded in the entire sample of the subset, and referred to as correct determinations. For example, if the subset contained only one of the three most common species, the number of correct determinations was 1 . The expected number of correct determinations over all possible combinations of one, two or three sites was calculated. A higher number of correct determinations is more representative of the entire sample. Obviously, as the number of sites increases, the number of correct determinations should also increase, and, therefore, the number of random site-years was limited to three or less.

Additionally, the number of wild bee species that were not among the three most abundant ones in the subset was calculated and referred to as incorrect determinations. Considering the same example as above, the number of incorrect determinations was 2 . The natural $\log$ of the ratio of correct determinations to incorrect determinations was calculated, which is the log-odds ratio of correct determinations. Incorrect determinations cause investigators to waste time on incorrect species, so a higher odds of being correct is indicative of less wasted time. As the number of species sampled increases from three to six, the number of incorrect determinations may also increase. These two statistics were calculated separately for sites that received or not the application of insecticides.

The focus on the three most common wild bee species was arbitrary. According to the collected data, the third most common species was $40 \%$ more abundant than the fourth most common species, representing a natural gap in the abundance distribution of the wild species. The odds were evaluated only for the three most common species. However, qualitatively similar results could be expected if a different number of wild species was considered.

Rare bee species were analyzed by retaining only those species with fewer than five specimens in the entire sample of the eight site-years. First, it was examined if the number of each species sampled per site was randomly distributed among sites. If individual occurrences were distributed randomly, the probability of occurrence would be Poisson distributed with mean equal to the total number of individuals caught, divided by the total number of possible species-site-year occurrences. The total number of possible species-site-year occurrences is the product of the number of site-years and the number of rare species.

Goodness of fit was tested with a log-linear model. It was also determined if the presence or absence of the species was randomly distributed among site-years. According to the null hypothesis, all site-years would have the same probability of species presence. This was also tested with a log-linear model. In addition, it was evaluated if insecticide application affected the presence or absence of rare species, using a log-linear model. Finally, species accumulation curves were used to assess if the eight site-years were sufficient to characterize the biological diversity of rare bees.

\section{Results and Discussion}

From 2003 to 2006, 3,470 specimens from 74 bee species were collected, during 344.6 hours of sampling in the eight site-years. Bees were the most abundant and diverse taxon in the assemblage of cotton-flower visitors. During 2003 and 2005, when all flower visitors were sampled, $49.6 \%$ of the 139 insect species and $52.2 \%$ of the 3,217 insects sampled belonged to three most abundant bee families.

The collected bee species belonged to the families Apidae (47 species, 63.51\%), Halictidae (24 species, $32.43 \%$ ), Andrenidae (2 species, $2.70 \%$ ), Megachilidae 
( 1 species, $1.35 \%$ ), and some are probably new species (Table 2). The most abundant native species on cotton flowers were Melissodes nigroaenea (Smith, 1854), Melissoptila cnecomola (Moure, 1944), Geotrigona mombuca (Smith, 1863), Paratrigona lineata (Lepeletier, 1836), Partamona mulata Moure, 1980, and Trigona spinipes (Fabricius, 1793); the last three are eusocial species.

The three most abundant wild bee species in the entire sample of the eight Cerrado sites were $P$. lineata, $M$. cnecomola, and $T$. spinipes. The sampled species richness was significantly correlated with sampling effort (in hours) $(\mathrm{r}=0.999$; $\mathrm{p}=0.026)$; more species were found in Distrito Federal (43) and less in Bahia (19). As expected, more species were collected in areas without insecticide use $(20.25 \pm 0.50)$ than in areas with insecticides (10.75 \pm 5.50$)$ (Kruskall-Wallis, $\mathrm{H}=5.600$; $\mathrm{df}=1 ; \mathrm{p}=0.018$ ). However, insecticide use did not influence the number of individuals collected per hour (relative abundance of all bees) (Kruskall-Wallis, $\mathrm{H}=1.333 ; \mathrm{df}=1 ; \mathrm{p}=0.248$ ).

Although the wild bee richness on cotton flowers was relatively high (74 species), it was lower than what might have been expected in the Cerrado. This biome, in which $92.5 \%$ of Brazilian cotton production occurs (Companhia Nacional de Abastecimento, 2012), is one of the biodiversity hotspots in South America (Myers et al., 2000) and is particularly rich in bees (Silveira \& Campos, 1995; Raw et al., 2002). More than 800 species of wild bees have been recorded in the Cerrado; 228 species in Distrito Federal alone $\left(5,801 \mathrm{~km}^{2}\right)$ (Raw et al., 2002). The morphology of Gossypium hirsutum flowers is expected to favor bee visitation, since it is typically entomophilous with one floral and four extrafloral nectaries, which attract bees and other insects (Free, 1993).

The rank-abundance curves showed that each bee assemblage was dominated by one or two very abundant species, followed by up to six moderately abundant species, and finally by a number of rare species (Figure 2). Apis mellifera predominates in the bee assemblages on cotton. This was the dominant species at all site-years. Paratrigona lineata and $M$. cnecomola were codominant in one site-year each, whereas, in the others, all wild bees were at least an order of magnitude less abundant than A. mellifera. The Simpson index (Bahia $=0.49$, Distrito Federal $=0.47$, and Mato Grosso=0.14) and the Shannon diversity index (Bahia=1.29, Distrito Federal=1.31, and Mato Grosso $=0.44$ ) also indicated that the assemblages were dominated by a few species.

Compared to honeybees, wild bees have several characteristics that may disfavor them in cotton environments of the Cerrado, including the following: they build their nests in natural substrates, such as tree cavities or directly in the soil (Michener, 2007) where they would be disturbed by conventional agricultural practices (Dormann et al., 2007); the wild social bees collected are not commercially raised; many of the wild species are more dependent on specific resources (food source, substrate for nest construction, etc.) that are absent or uncommon near cultivated fields; and the solitary bees killed by insecticide application in cotton fields are foragers and reproductive individuals, since all their females are reproductive (Michener, 2007). Besides crop management (Dormann et al., 2007; Le Féon et al., 2010; Brittain \& Potts, 2011), other factors may have limited wild bee species richness in the cotton areas. Cotton flowers are ephemeral and available for 90 days at most in the Central-West region of Brazil (Rosolem, 2007); moreover, the fragments of remnant Cerrado vegetation near cotton fields in this region are generally small and highly disturbed (Sparovek et al., 2010), limiting the source of wild bees.

The accumulation curves for the bee species were plotted with and without rare species (Figure 3). When only the common species were considered, the curves reached an asymptote for Distrito Federal and Mato Grosso, suggesting that the sampling effort was sufficient to capture the common wild species present on cotton flowers. When all species were considered, the accumulation curves did not level off as clearly, but they still suggest that most species were sampled in Distrito Federal and Mato Grosso. In Bahia, however, the curves with and without the rare species did not reach an asymptote, which indicates that the bee assemblage could be more diverse.

Seventeen bee species, including A. mellifera, were identified as common to all areas. The similarity between pairs of sites for common bee species averaged $71 \%$, indicating high similarity and little species turnover. The highest similarity was observed between the Distrito Federal-Coperbrás/2005 and Mato Grosso-Primavera do Leste/2005 (94\%) sites, which are about $600 \mathrm{~km}$ apart, and the lowest similarity was also found between them - Distrito 
Table 2. Relative abundance of bee species collected on cotton (Gossypium hirsutum var. latifolium) flowers, in different years and localities in the Cerrado phytogeographic domain of Brazil.

\begin{tabular}{|c|c|c|c|c|c|c|c|c|}
\hline \multirow[t]{2}{*}{ Family and species } & \multicolumn{8}{|c|}{ Relative abundance $^{(1)}$} \\
\hline & S1 & S2 & S3 & S4 & S5 & S6 & S7 & S8 \\
\hline \multicolumn{9}{|l|}{ Andrenidae } \\
\hline Acamptopoeum prinii & - & - & - & - & 0.03 & - & - & - \\
\hline Rhophitulus sp. & 0.02 & - & - & - & 0.03 & - & - & - \\
\hline Apidae & & & & & & & & \\
\hline Alepidosceles imitatrix & - & - & - & - & - & 0.80 & 0.01 & 0.04 \\
\hline Apis mellifera & 2.57 & 2.06 & 2.02 & 3.48 & 6.86 & 27.06 & 10.68 & 4.46 \\
\hline Bombus (Fervidobombus) atratus & - & - & 0.06 & 0.05 & - & - & - & - \\
\hline Bombus (Fervidobombus) morio & 0.07 & 0.09 & 0.12 & - & - & - & - & - \\
\hline Centris (Melacentris) cfr. collaris & - & - & - & - & 0.03 & - & - & - \\
\hline Centris (Ptilotopus) scopipes & 0.02 & - & - & - & 0.03 & - & - & - \\
\hline Centris (Ptilotopus) sp. & 0.02 & - & - & - & - & - & - & - \\
\hline Ceratina (Crewella) $\mathrm{cfr}$ asuncionis ${ }^{(2)}$ & - & - & - & 0.03 & 0.06 & - & - & - \\
\hline Ceratina (Crewella) cfr. gossypii & - & - & - & - & - & 0.21 & - & - \\
\hline Ceratina (Crewella) sp. 1 & - & - & - & - & - & 0.02 & - & - \\
\hline Diadasina riparia & - & - & - & - & - & - & - & 0.04 \\
\hline Diadasina cfr. paraensis & - & - & - & - & - & 0.05 & - & - \\
\hline Epicharis bicolor & - & - & - & - & - & - & 0.01 & - \\
\hline Eufriesea $\mathrm{cfr}$. auriceps & 0.02 & _- & 0.06 & - & _- & _- & - & _- \\
\hline Eulaema (Apeulaema) nigrita & - & - & - & 0.03 & - & - & 0.01 & 0.04 \\
\hline Exomalopsis (Exomalopsis) analis & 0.07 & - & - & - & 0.03 & - & 0.07 & 0.08 \\
\hline Exomalopsis (Exomalopsis) auropilosa & 0.05 & - & - & - & - & - & 0.01 & - \\
\hline Exomalopsis (Exomalopsis) fulvofasciata & - & _- & - & - & _- & - & - & 0.04 \\
\hline Exomalopsis (Exomalopsis) sp.1 & 0.02 & - & - & 0.03 & - & - & - & 0.12 \\
\hline Exomalopsis (Exomalopsis) sp.2 & - & - & - & - & - & - & - & 0.08 \\
\hline Frieseomelitta varia & - & - & - & - & - & 0.05 & - & - \\
\hline Frieseomelitta doederleini & - & - & - & - & - & - & 0.03 & 0.04 \\
\hline Florilegus (Euflorilegus) festivus & - & - & - & - & - & 0.05 & - & - \\
\hline Geotrigona mombuca & - & - & - & - & - & 0.02 & - & 0.31 \\
\hline Melipona (Melikerria) quinquefasciata & - & - & 0.06 & - & - & - & - & - \\
\hline Melissodes (Ecplectica) nigroaenea & 0.10 & - & - & 0.30 & 0.44 & 0.02 & 0.16 & - \\
\hline Melissoptila cnecomola & 0.02 & 0.02 & _- & 1.58 & 0.33 & - & - & _- \\
\hline Melissoptila cfr. pubescens & - & - & - & 0.03 & 0.14 & - & - & - \\
\hline Melitoma segmentaria ${ }^{(2)}$ & - & - & - & - & - & - & - & - \\
\hline Paratrigona lineata ${ }^{(2)}$ & 1.28 & 0.02 & 0.80 & 0.40 & 0.22 & 0.62 & - & 0.12 \\
\hline Partamona cfr. cupira & - & - & - & - & 0.19 & - & - & - \\
\hline Partamona cfr. mulata & - & - & - & - & - & 0.57 & - & - \\
\hline Ptilothrix cfr. plumata ${ }^{(2)}$ & - & - & - & 0.03 & 0.06 & 0.05 & - & - \\
\hline Schwarziana quadripunctata & - & - & - & - & 0.03 & - & - & - \\
\hline Tapinotaspoides serraticornis & - & - & - & - & - & 0.02 & - & - \\
\hline Tetragona clavipes & - & 0.02 & - & - & - & - & - & - \\
\hline Trigona cfr. fuscipennis & - & - & - & - & - & - & 0.03 & - \\
\hline Trigona hyalinata & - & - & - & 0.03 & - & - & - & - \\
\hline Trigona recursa & - & - & - & - & - & 0.05 & - & - \\
\hline Trigona spinipes & 0.44 & 0.23 & 0.12 & 0.05 & 0.19 & 0.11 & - & 0.62 \\
\hline Trigona truculenta $^{(3)}$ & - & - & - & - & - & - & - & - \\
\hline Trigona $\mathrm{sp}^{(3)}$ & - & - & - & - & - & - & - & - \\
\hline Trigonisca $\mathrm{sp}$. & 0.02 & - & - & - & - & - & - & - \\
\hline Xylocopa grisescens & - & - & - & - & - & 0.02 & - & - \\
\hline Xylocopa hirsutissima & - & - & - & - & - & 0.02 & - & - \\
\hline Xylocopa suspecta & - & - & - & - & - & 0.05 & - & - \\
\hline Xylocopa $\mathrm{sp}$. & - & - & - & - & - & - & 0.01 & - \\
\hline Halictidae & & & & & & & & \\
\hline Augochlora (Augochlora) sp. & _- & _- & _- & - & 0.11 & _- & _- & _- \\
\hline Augochlora (Augochlora) sp. $1^{(2)}$ & - & - & - & - & - & - & - & - \\
\hline Augochlora (Augochlora) sp.2 & - & - & - & 0.03 & - & - & - & - \\
\hline Augochlora (Augochlora) sp.4 & - & - & - & - & - & - & - & 0.08 \\
\hline Augochlora (Augochlora) dolichocephala & - & - & - & 0.08 & - & - & - & - \\
\hline Augochlora (Augochlora) esox & - & - & - & 0.08 & - & - & - & - \\
\hline Augochlora (Oxystoglossela) morrae & - & - & - & 0.05 & - & - & - & - \\
\hline Augochlora (Oxystoglossela) thalia ${ }^{(2)}$ & - & - & - & 0.10 & - & 0.05 & - & - \\
\hline Augochlorella cfr. acarinata & - & - & - & - & - & - & 0.01 & - \\
\hline Augochloropsis sp.1 & 0.10 & - & - & - & - & - & - & - \\
\hline Augochloropsis sp.2 & 0.05 & - & - & - & - & - & - & 0.04 \\
\hline Augochloropsis sp. $3^{(2)}$ & 0.02 & - & - & - & - & - & - & - \\
\hline Augochloropsis sp.4 & 0.02 & - & - & - & - & - & - & - \\
\hline Augochloropsis patens & 0.05 & - & - & 0.05 & 0.03 & - & - & - \\
\hline Ceratalictus sp. 1 & 0.02 & - & - & - & - & - & - & - \\
\hline Ceratalictus sp. 2 & - & - & - & - & 0.03 & 0.02 & - & - \\
\hline Dialictus sp.1 & 0.05 & - & - & - & - & - & - & - \\
\hline Dialictus sp.2 & - & _- & _- & 0.03 & 0.03 & _- & - & - \\
\hline Dialictus sp.3 & - & - & - & - & - & - & - & 0.04 \\
\hline Dialictus sp.5 & - & - & - & - & - & - & - & 0.04 \\
\hline Dialictus sp.7 & - & - & - & - & - & - & 0.01 & - \\
\hline Dialictus sp. 8 & - & - & - & 0.03 & 0.03 & - & - & - \\
\hline Pereirapis sp. & - & - & - & - & - & - & - & 0.04 \\
\hline Pseudaugochlora graminea & - & - & - & - & - & - & - & 0.04 \\
\hline Megachilidae & & & & & & & & \\
\hline Lithurgus (Lithurgus) huberi & - & _- & _- & 0.08 & _- & _- & _- & 0.08 \\
\hline Total of individuals & 206 & 107 & 53 & 257 & 320 & 1,308 & 748 & 164 \\
\hline Total of species & 21 & 6 & 7 & 20 & 20 & 20 & 12 & 18 \\
\hline Relative abundance of total fauna collected & 5.09 & 2.48 & 3.25 & 6.43 & 8.89 & 29.84 & 11.08 & 6.31 \\
\hline
\end{tabular}


Federal-Coperbrás/2003 and Mato Grosso-Primavera do Leste/2005 (52.8\%). Common species tend to have a wide geographic distribution.

The first two PCA components explained 52.7\% of the total variability in the rank abundance of the common species among the eight site-years. All site-years that received insecticide applications clustered together in the lower left quadrant (Figure 4). These included site-years from all three states, indicating that insecticides influenced the common bee assemblage more than geographical location.
The Distrito Federal-Embrapa Hortaliças/2005 and Distrito Federal-Embrapa Hortaliças/2006 sites clustered together in the upper right quadrant, indicating that the common bees were consistent at these sites over the two years. Species such as Partamona cupira (Smith, 1863), Melissoptila cfr. pubescens (Smith, 1879), M. nigroaenea, and M. cnecomola were associated with these site-years (Distrito Federal-Embrapa Hortaliças/2005 and 2006). The other two site-years without insecticide spray (S1 = Distrito Federal-Coperbrás/2003; S6 = Mato
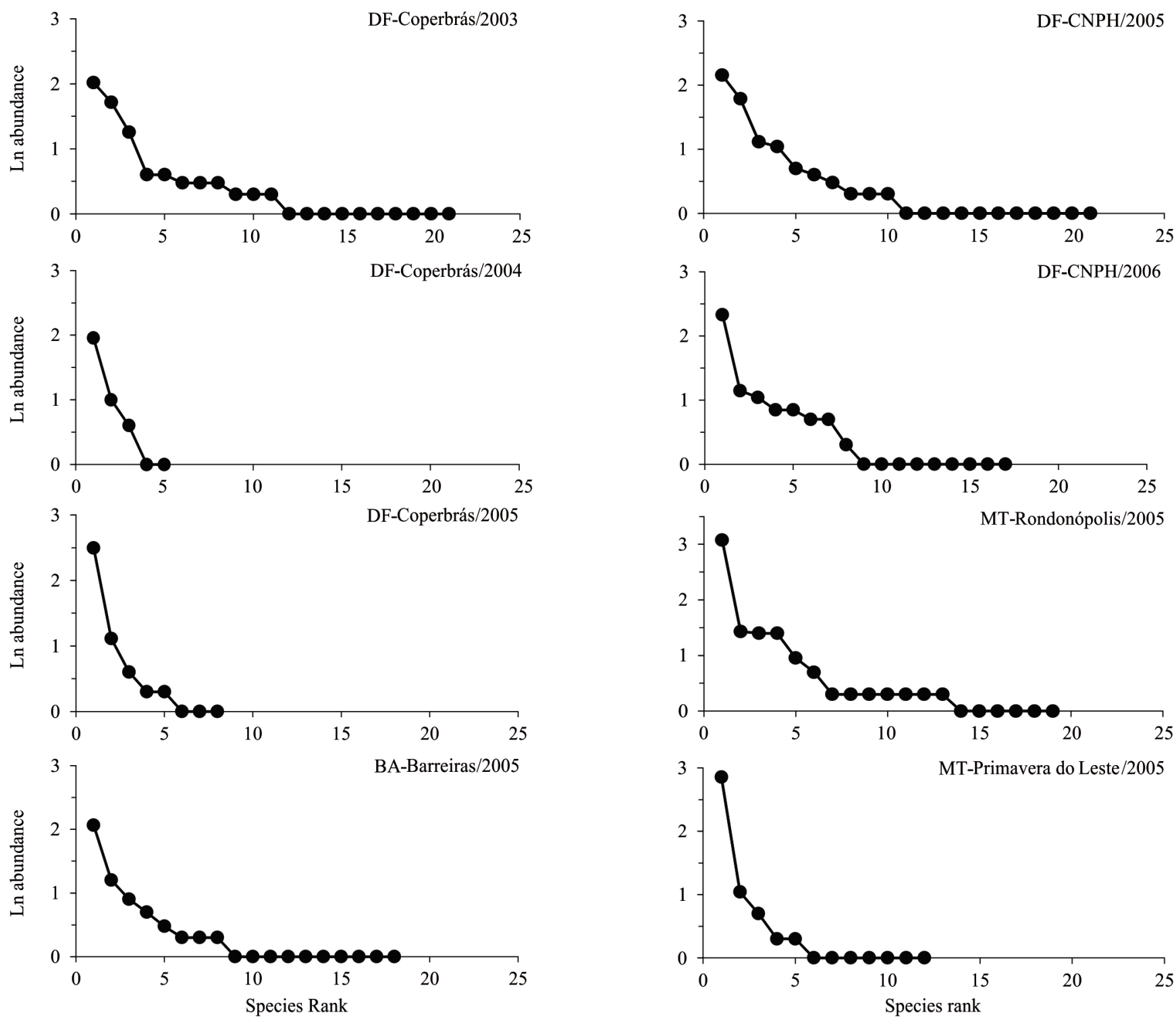

Figure 2. Rank-abundance pattern of the bee assemblages sampled on cotton (Gossypium hirsutum var. latifolium) flowers, based on data sets from different years and sites in the Central-West region of Brazil. DF, Distrito Federal; BA, Bahia; MT, Mato Grosso; and CNPH, Embrapa Hortaliças. 
Grosso-Rondonópolis/2005) were widely separated. All of the Distrito Federal-Coperbrás site-years were relatively close together, probably indicating that interannual variation in bee assemblages was low.

Because insecticides had a strong effect on common bee species, the number of site-years needed to correctly determine the three most common wild bee species was estimated, for sites receiving insecticides and for those that did not receive insecticides. These species were $P$. lineata, $M$. cnecomola, and $T$. spinipes. As anticipated, the expected number of correct determinations increased for the insecticide-free sites,
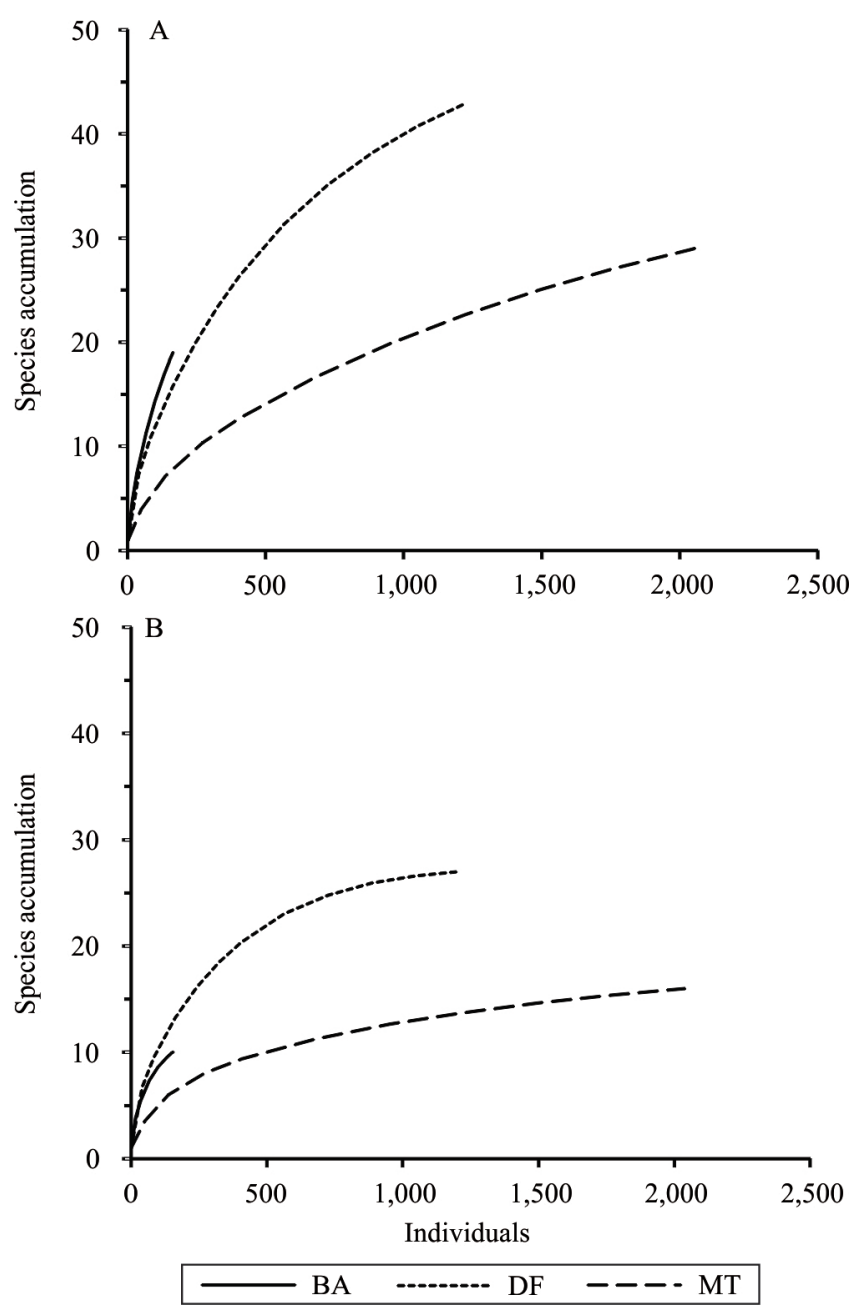

Figure 3. Species accumulation curves for wild bees collected on cotton (Gossypium hirsutum var. latifolium) flowers in different localities of Central-West regions of Brazil, from 2003 to 2006: BA, Bahia; DF, Distrito Federal; and MT, Mato Grosso. A, data set with the rare species; B, data set without the rare species. as the number of bee species in the sample increased, reaching an average of 2.8 correct determinations out of the possible three species (Figure 5). However, when more species were included in the sample, more species were incorrectly determined as one of the three most common wild bee species (Figure 6). For example, if the five most abundant species were selected in a sample, then, even if the three most common species were correctly included, there would be at least two incorrect species. Consequently, the ratio between correct and incorrect determinations (or log-ratio) can

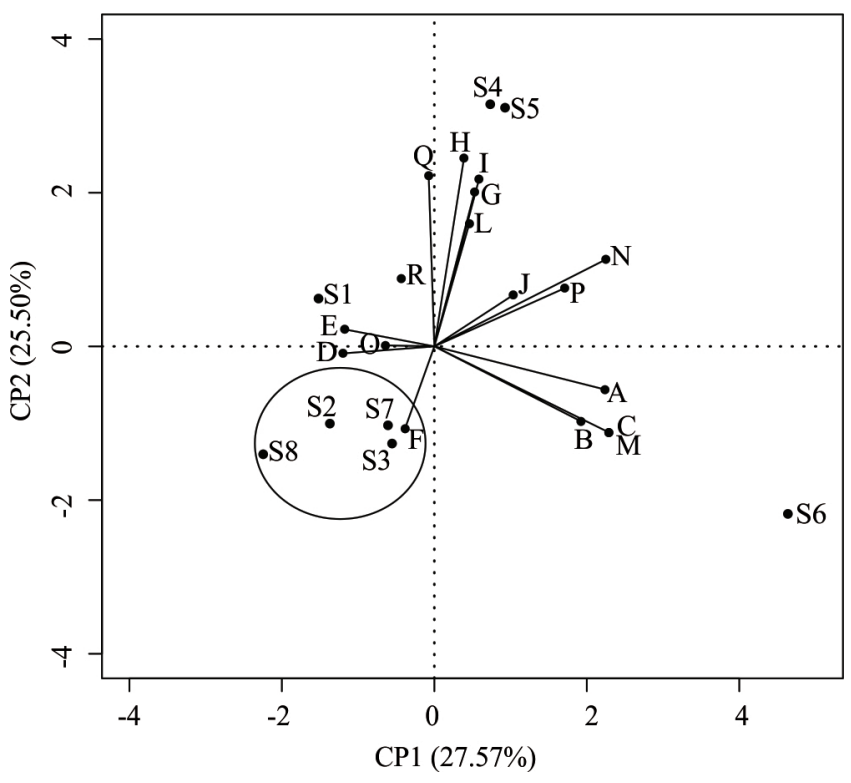

Figure 4. The first two principal component axes of the bee assemblages on cotton (Gossypium hirsutum var. latifolium) flowers, in all site-years sampled in Central-West Brazil. Site-years (S): S1, DF-Coperbrás/2003; S2, DF-Coperbrás/2004; S3, DF-Coperbrás/2005; S4, DF-CNPH/2005; S5, DF-CNPH/2006; S6, MT-Rondonópolis/2005; S7, MT-Primavera do Leste/2005; and S8, BA-Barreiras/2005; in which DF, MT, and BA refer to Distrito Federal, Mato Grosso, and Bahia, respectively, and CNPH refers to Embrapa Hortaliças. The site-years S2, S3, $\mathrm{S} 7$, and $\mathrm{S} 8$ received insecticides. Bee species are indicated by letters: A, Alepidosceles cfr. imitatrix; B, Apis mellifera; C, Ceratina (Crewella) cfr. gossypii; D, Exomalopsis (Exomalopsis) analis; E, Exomalopsis (Exomalopsis) sp. 1; F, Geotrigona mombuca; G, Melissodes (Ecplectica) nigroaenea; H, Melissoptila cnecomola; I, Melissoptila cfr. pubescens; J, Paratrigona lineata; L, Partamona cupira; M, Partamona mulata; N, Ptilothrix cfr. plumata; O, Trigona spinipes; P, Augochlora (Oxystoglossella) thalia; Q, Augochloropsis patens; and R, Lithurgus (Lithurgus) huberi. 
be used to find the smallest number of sampled species and the smallest number of sites needed in order to identify the three most common wild bee species. A higher number of correct determinations, compared to incorrect ones, occurred only for three and four species samples (Figure 6). The most accurate method for identifying the three most common wild species is to sample two site-years and include the four most common species from each site. With this method, the
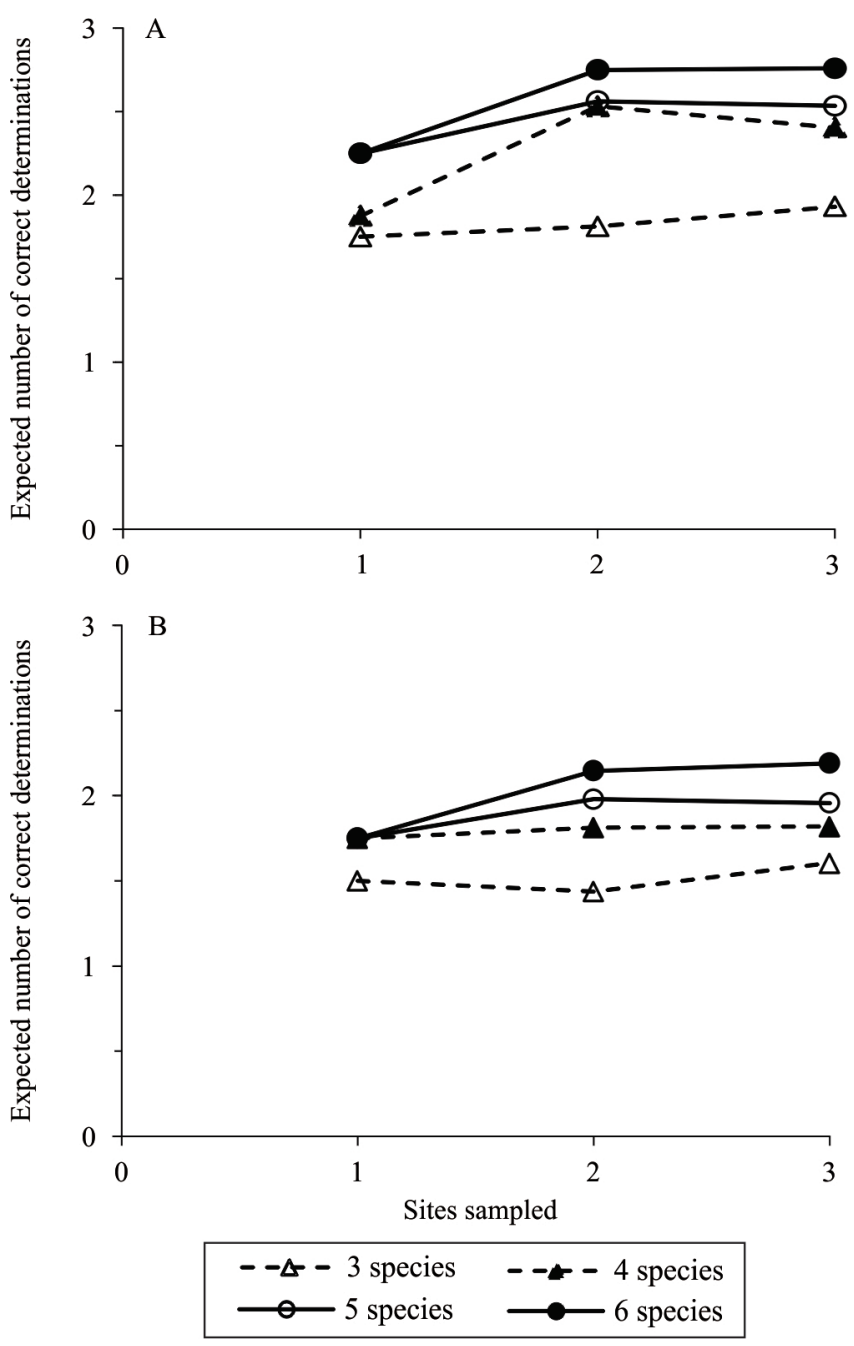

Figure 5. Expected number of correct determinations of the three most common wild bee species on cotton (Gossypium hirsutum var. latifolium) flowers, among the abundant species in random samples over all possible combinations of one, two or three site-years. The expected number was calculated for the 3, 4, 5, and 6 most abundant species in a sample. A, site-years that did not receive insecticides; and B, site-years that received insecticides. expected number of correctly identified species of the three most common species would be 2.5 .

For the sites that received insecticide applications, the expected number of correct determinations peaked at 2.2, but, because the assemblages were highly similar, the number of correct determinations did not change very much (Figure 5). In addition, the number of incorrect determinations typically exceeded the number of correct ones (Figure 6), probably because only one to two wild species were common in these sites. Therefore, sampling sites that received insecticides will probably not clearly identify the most common wild species visiting cotton flowers.
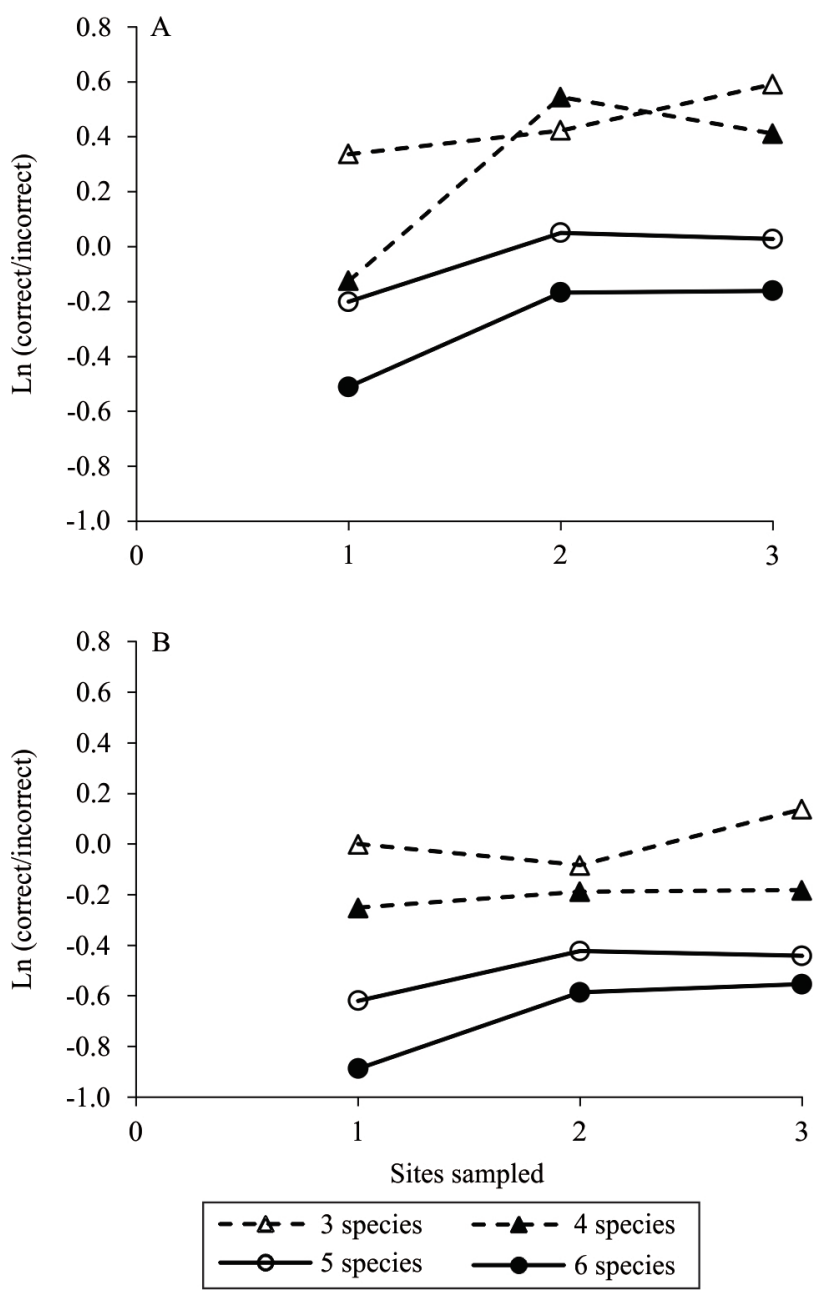

Figure 6. Natural log of the ratio between the expected number of common wild bee species correctly determined and the number incorrectly determined. A, site-years that did not receive insecticides; and $\mathrm{B}$, site-years that did receive insecticides. 
The abundance of rare bee species was not Poisson distributed among sites $\left(\mathrm{g}^{2}=29.40 ; \mathrm{df}=4 ; \mathrm{p}=6.49 \times 10^{-6}\right)$, and rare species were spatially aggregated by abundance. Some of these rare species may be locally abundant but geographically restricted or temporally variable.

Rare species occurred more often in insecticide-free sites than in sites with insecticide use $\left(\mathrm{g}^{2}=4.38 ; \mathrm{df}=1\right.$; $\mathrm{p}=0.036$ ). There were $12.7 \pm 3.8$ (mean \pm standard-error) occurrences of rare species per 100 sampling hours in the sites with insecticide use, and more than twice this number $(26.3 \pm 2.1)$ in the insecticide-free sites. Presence of rare species was randomly distributed among the sites with insecticide use and among the insecticide-free sites $\left(\mathrm{g}^{2}=4.06 ; \mathrm{df}=6 ; \mathrm{p}=0.669\right)$, which means that the presence of rare species is not spatially aggregated. Therefore, the adequacy of sampling rare species is related to the number of sites sampled, in addition to the local sampling effort.

The species accumulation curves for rare bees in insecticide-use site-years, insecticide-free site-years, or in both combined, showed that the sample did not recover a significant proportion of rare bee species associated with cotton (Figure 7). None of the curves tended to an asymptote, and increasing the sample effort resulted in more rare species. Therefore, a higher

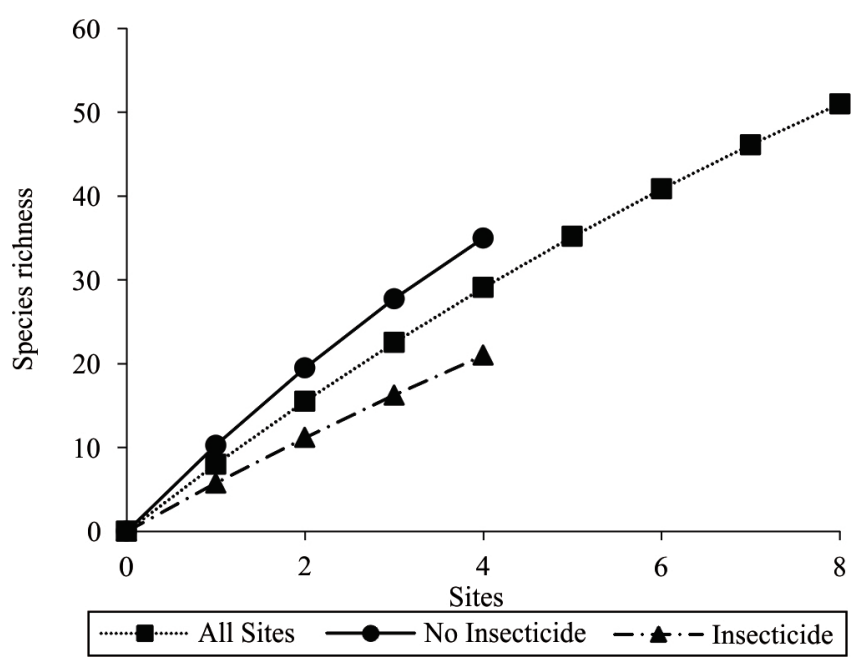

Figure 7. Species accumulation curves for rare bee species collected on cotton (Gossypium hirsutum var. latifolium) flowers in sites that received insecticide applications and in insecticide-free sites, or in both combined. Rare species, species represented by fewer than five specimens in the entire sample from eight sites. number of rare bee species is likely to be associated with cotton in the Cerrado biome. To collect these additional rare species, further sampling sites may be necessary throughout the region.

The inventory effort needed to choose pollinator species for ERA purposes is different for the evaluation of pollination services and for the assessment of pollinator biological diversity or for conservation interest. For pollination services, ERA should focus on the most abundant and most extensively distributed species in the cultivation areas (Arpaia et al., 2006; Sanvido et al., 2012). For pollinator biological diversity, it may be more important to consider the rare bee species, since they are the bulk of the bee diversity found on cotton flower.

The three most common wild bee species ( $P$. lineata, $T$. spinipes, and M. cnecomola) found in cotton areas in Central-West region of Brazil could be identified with relatively little inventory effort. The obtained results suggest that samples from the two cotton site-years that did not receive insecticides would suffice to identify on average 2.5 of the three species with log odds of 0.54 (Figures 5 and 6). In addition to A. mellifera, any of these three species could be used to assess the impact of a new cotton technology on pollinator services. Further information about foraging behavior of these three species is needed to assess their effect on cotton pollination and on cotton pollen dispersal, in order to determine which bee species is the most suited for ERA in transgenic cotton.

However, if the interests are in the conservation of pollinator diversity, a higher sampling effort would be necessary than the eight site-years and 344.6 hours of sampling conducted here, in order to construct a reasonably complete list of rare species that visit cotton and that could be affected by a change in cotton production technology. The species accumulation curves in the evaluated sample did not reach a plateau, so many of the rare species associated with cotton were overlooked. Site-years with insecticide application accumulated rare species faster than site-years without insecticides; therefore, additional sampling should be done on sites without insecticides. None of the rare wild species in the studied sample are listed as an endangered species in Brazil, but this may be just a consequence of the scarcity of information on them (Machado et al., 2008).

Pesq. agropec. bras., Brasília, v.49, n.8, p.573-586, ago. 2014 DOI: 10.1590/S0100-204X2014000800001 
Because rare bees require great sampling effort, effects on species richness may be more readily observed by measuring the rate of bee species accumulation per sampling effort. The present study suggests that a reduced rate of rare bee species accumulation may be a useful ERA indicator of adverse effects on bee diversity in the Cerrado.

This ecological approach to species selection for ERA is in accordance with the requirements of the Cartagena Protocol (Cartagena protocol on biosafety to the convention on biological diversity, 2000). Moreover, it provides guidance for conducting inventories on pollinator biological diversity associated with any agroecosystem, which would help other countries in these international agreements. Ecological approaches using modest field inventory effort can identify ecological indicators for ERA associated with GM cotton technology in Central-West region of Brazil. A similar approach could be used to assess the impacts of other agricultural technologies in the Cerrado and could be applied to other crops, helping to develop an environmentally sustainable agriculture in this biome.

\section{Conclusions}

1. Impacts on pollination services can be evaluated using geographically widespread, common pollinator bee species, whereas impacts on pollinator biological diversity must focus on rare bee species.

2. The species Apis mellifera dominates the bee assemblages in all sites.

3. Inventories conducted in two sites that did not receive insecticide applications are sufficient to identify the three most geographically widespread and common wild bee species, which are: Paratrigona lineata, Melissoptila cnecomola, and Trigona spinipes, all of them a potentially useful indicator of pollination services.

4. Indirect ordination of common wild bee species revealed that insecticides may have reduced the number of bee species and that interannual variation in bee assemblages may be low.

5. Species-based approaches may be limited for analyzing the impacts on pollinator biological diversity, and the accumulation rate of rare bee species may be a useful ecological indicator for environmental risk assessment.

\section{Acknowledgments}

To Gisele Oliveira, Erich Nakasu, Laura Cavéchia, and João A. Sálame, for helping in the field work; to Empresa Brasileira de Pesquisa Agropecuária (Embrapa), to Financiadora de Estudos e Projetos (Finep), and to Fundo de Apoio à Cultura do Algodão (Facual), for scholarship granted to the third author.

\section{References}

ANDOW, D.A.; HILBECK, A. Science-based risk assessment for non-target effects of transgenic crops. BioScience, v.54, p.637-649, 2004. DOI: 10.1641/0006-3568(2004)054[0637:SRAFNE]2.0. $\mathrm{CO} ; 2$.

ANDOW, D.A.; LÖVEI, G.L.Q.; ARPAIA, S.; LEWIS, W.; FONTES, E.M.G.; HILBECK, A.; LANG, A.; TUÂT, N.V.; PIRES, C.S.S.; SUJI, E.R.; ZWAHLEN, C.; BIRCH, A.N.E.; CAPALBO, D.M.F.; PRESCOTT, K.; OMOTO, C.; ZEILINGER, A.R. An ecologically-based method for selecting ecological indicators for assessing risks to biological diversity from genetically-engineered plants. Journal of Biosafety, v.22, p.141-156, 2013.

ANDOW, D.A.; ZWAHLEN, C. Assessing environmental risks of transgenic plants. Ecology Letters, v.9, p.196-214, 2006. DOI: 10.1111/j.1461-0248.2005.00846.x.

ARPAIA, S.; DE CRISTOFARO, A.; GUERRIERI, E.; BOSSI, S.; CELLINI, F.; DI LEO, G.M.; GERMINARA, G.S.; IODICE, L.; MAFFEI, M.E.; PETROZZA, A.; SASSO, R.; VITAGLIANO, S. Foraging activity of bumblebees (Bombus terrestris L.) on Bt-expressing eggplants. Arthropod-Plant Interactions, v.5, p.255-261， 2011. DOI: 10.1007/s11829-011-9144-5. DOI: 10.1007/s11829-011-9144-5.

ARPAIA, S.; FONSECA, V.L.I.; PIRES, C.S.; SILVEIRA, F.A. Non-target and biodiversity impacts on pollinators and flower-visiting insects. In: HILBECK, H.; ANDOW, D.A.; FONTES, E.M.G. (Ed.). Environmental risk assessment of genetically modified organisms: volume 2 - methodologies for assessing Bt cotton in Brazil. Wallingford: CABI, 2006. p.155-174.

BRITTAIN, C.; POTTS, S.G. The potential impacts of insecticides on the life-history traits of bees and the consequences for pollination. Basic and Applied Ecology, v.12, p.321-331, 2011. DOI: 10.1016/j.baae.2010.12.004.

CARTAGENA protocol on biosafety to the convention on biological diversity: text and annexes. Montreal: Secretariat of the Convention on Biological Diversity, 2000. 19p.

COMPANHIA NACIONAL DE ABASTECIMENTO. Levantamentos de safra: levantamento da safra de grãos, café, cana-de-açúcar e laranja (área plantada, produtividade e produção). Disponível em: <http://www.conab.gov.br/conteudos. php? $\mathrm{a}=1253 \& \mathrm{t}=2>$. Acesso em: $11 \mathrm{dez} .2012$.

DORMANN, C.F.; SCHWEIGER, O.; AUGENSTEIN, I.; BAILEY, D.; BILLETER, R.; BLUST, G.; DEFILIPPI, R.; FRENZEL, M.; HENDRICKX, F.; HERZOG, F.; KLOTZ, S.; LIIRA, J.; MAELFAIT, J.-P.; SCHMIDT, T.; SPEELMANS, M.; 
VAN WINGERDEN, W.K.R.E.; ZOBEL, M. Effects of landscape structure and land-use intensity on similarity of plant and animal communities. Global Ecology and Biogeography, v.16, p.774-787, 2007. DOI: 10.1111/j.1466-8238.2007.00344.x.

FORBES, V.E.; FORBES, T.L. Ecotoxicology in theory and practice. London: Chapman and Hall, 1994. 253p. (Ecotoxicology series, 2).

FREE, J.B. Insect pollination of crops. London: Academic Press, 1993. 768p.

HAN, P.; NIU, C.-Y.; LEI, C.-L.; CUI, J.J.; DESNEUX, N. Quantification of toxins in a Cry1Ac+CpTI cotton cultivar and its potential effects on the honey bee $A$. mellifera L. Ecotoxicology, v.19, p.1452-1459, 2010. DOI: 10.1007/s10646-010-0530-z.

HARE, J.D. Ecological role of volatiles produced by plants in response to damage by herbivorous insects. Annual Review of Entomology, v.56, p.161-180, 2011. DOI: 10.1146/ annurev-ento-120709-144753.

HAYES, K.R. Best practice and current practice in ecological risk assessment for genetically modified organisms. Hobart: CSIRO Division of Marine Research, 2002. 78p.

HEARD, T.A. The role of stingless bees in crop pollination. Annual Review of Entomology, v.44, p.183-206, 1999. DOI: 10.1146/annurev.ento.44.1.183.

HILBECK, A.; ANDOW, D.A.; ARPAIA, S.; BIRCH, A.N.E.; FONTES, E.M.G.; LÖVEI, G.L.; SUJII, E.; WHEATLEY, R.E.; UNDERWOOD, E. Methodology to support non-target and biodiversity risk assessment. In: HILBECK, A.; ANDOW, D.A.; FONTES, E.M.G. (Ed.). Environmental risk assessment of genetically modified organisms series: volume 2 - methodologies for assessing Bt cotton in Brazil. Wallingford: CABI, 2006. p.108-132.

HILL, R.A. Conceptualizing risk assessment methodology for genetically modified organisms. Environmental Biosafety Research, v.4, p.67-70, 2005. DOI: 10.1051/ebr:2005012.

HONG, L.T.T.; TÂM, Đ.Q.; TUÂN, H.A.; LAI, T.K.; LÖVEI, G.L.; PIRES, C.S.S.; WAN, F.-H.; GUO, J.-Y.; ANDOW, D.A. Potential effects of transgenic cotton on flower visitors in Vietnam. In: ANDOW, D.A.; HILBECK, A.; TUAT, N. van. (Ed.). Environmental risk assessment of genetically modified organisms: challenges and opportunities with $\mathrm{Bt}$ cotton in Vietnam. Wallingford: CABI, 2008. p.236-257. DOI: 10.1079/9781845933906.0000.

KREBS, C.J. Ecological methodology. Menlo Park: Addison Wesley, 1998. 620p.

KREMEN, C.; WILLIAMS, N.M.; AIZEN, M.A.; GEMMILL-HERREN, B.; LEBUHN, G.; MINCKLEY, R.; PACKER, L.; POTTS, S.G.; ROULSTON, T.; STEFFAN-DEWENTER, I.; VÁZQUEZ, D.P.; WINFREE, R.; ADAMS, L.; CRONE, E.E.; GREENLEAF, S.S.; KEITT, T.H.; KLEIN, A.-M.; REGETZ, J.; RICKETTS, T.H. Pollination and other ecosystem services produced by mobile organisms: a conceptual framework for the effects of land-use change. Ecology Letters, v.10, p.299-314, 2007. DOI: 10.1111/j.1461-0248.2007.01018.x.
LE FÉON, V.; SCHERMANN-LEGIONNET, A.; DELETTRE, Y.; AVIRON, S.; BILLETER, R.; BUGTER, R.; HENDRICKX, F.; BUREL, F. Intensification of agriculture, landscape composition and wild bee communities: a large scale study in four European countries. Agriculture, Ecosystems and Environment, v.137, p.143-150, 2010. DOI: 10.1016/j.agee.2010.01.015.

MACHADO, A.B.M.; DRUMMOND, G.M.; PAGLIA, A.P. Livro vermelho da fauna brasileira ameaçada de extinção. Volume I invertebrados terrestres. Brasília: Ministério do Meio Ambiente, 2008. v.1, 1420p. (MMA. Biodiversidade, 19).

MICHENER, C.D. The bees of the world. $2^{\text {nd }}$ ed. Baltimore: The Johns Hopkins University, 2007. 953p.

MOURE, J.M.; URBAN, D.; MELO, G.A.R. Catalogue of bees (Hymenoptera, Apoidea) in the Neotropical Region. Curitiba: Sociedade Brasileira de Entomologia, 2007. 1058p.

MYERS, N.; MITTERMEIER, R.A.; MITTERMEIER, C.G.; FONSECA, G.A.B.; KENT, J. Biodiversity hotspots for conservation priorities. Nature, v.403, p.853-858, 2000. DOI: $10.1038 / 35002501$.

NATIONAL RESEARCH COUNCIL. Environmental effects of transgenic plants: the scope and adequacy of regulation. Washington: National Academy Press, 2002. 320p.

NATIONAL RESEARCH COUNCIL. Risk assessment in the Federal Government: managing the process. Washington: National Academy Press, 1983. 192p.

PINHEIRO-MACHADO, C.; ALVES-DOS-SANTOS, I.; IMPERATRIZ-FONSECA, V.L.; KLEINERT, A.M.P.; SILVEIRA, F.A. Brazilian bee surveys: state of knowledge, conservation and sustainable use. In: KEVAN, P.G.; IMPERATRIZ-FONSECA, V.L. (Ed.). Pollinating bees: the conservation link between agriculture and nature. Brasília: Ministério do Meio Ambiente, 2002. p.115-129.

R DEVELOPMENT CORE TEAM. R: a language and environment for statistical computing. Vienna: R Foundation for Statistical Computing, 2010.

RAW, A.; BOAVENTURA, M.C.; FREITAS, G.S. The diversity of a bee fauna: the species of the cerrados of Central Brazil. In: KEVAN, P.G.; IMPERATRIZ-FONSECA, V.L. (Ed.). Pollinating bees: the conservation link between agriculture and nature. Brasília: Ministério do Meio Ambiente, 2002. p.255-299.

ROSOLEM, C.A. Fenologia e ecofisiologia no manejo do algodoeiro. In: FREIRE, E.C. (Ed.). Algodão no cerrado do Brasil. Brasília: Abrapa, 2007. p.649-688.

SANVIDO, O.; ROMEIS, J.; GATHMANN, A.; GIELKENS, M.; RAYBOULD, A.; BIGLER, F. Evaluating environmental risks of genetically modified crops: ecological harm criteria for regulatory decision-making. Environmental Science and Policy, v.15, p.82-91, 2012. DOI: 10.1016/j.envsci.2011.08.006.

SENSI, A.; BRANDENBERG, O.; GHOSH, K.; SONNINO, A. Biosafety resources: module risk analysis. Rome: Food and Agriculture Organization of the United Nations, 2011. 81p.

SILVEIRA, F.A.; CAMPOS, M.J.O. A melissofauna de Corumbataí (SP) e Paraopeba (MG) e uma análise da biogeografia das abelhas 
do cerrado brasileiro (Hymenoptera, Apoidea). Revista Brasileira de Entomologia, v.39, p.371-401, 1995.

SILVEIRA, F.A.; GODÍNEZ, L.M. Systematic surveys of local bee faunas. Melissa, v.9, p.1-4, 1996.

SPAROVEK, G.; BERNDES, G.; KLUG, I.L.F.; BARRETTO, A.G.O.P. Brazilian agriculture and environmental legislation: status and future challenges. Environmental Science and Technology, v.44, p.6046-6053, 2010. DOI: 10.1021/es1007824.

STARK, J.D.; BANKS, J.E.; VARGAS, R. How risky is risk assessment: the role that life history strategies play in susceptibility of species to stress. Proceedings of the National Academy of Sciences of the United States of America, v.101, p.732-736, 2004. DOI: 10.1073/pnas.0304903101.

SUTER II, G.W. Ecological risk assessment. $2^{\text {nd }}$ ed. Boca Raton: CRC Press, 2007. 655p.

VAN ENGELSDORP, D.; MEIXNER, M.D. A historical review of managed honey bee populations in Europe and the United States and the factors that may affect them. Journal of Invertebrate Pathology, v.103, p.S80-S95, 2009. DOI: 10.1016/j. jip.2009.06.011.

Received on March 3, 2014 and accepted on August 12, 2014 